\title{
An Investigation of Activities of Microfinance Banks As a Veritable Tool for Reducing Poverty and Unemployment in Developing Economies. The Evidence From Nigeria
}

\author{
I.A. Onoyere, Ph.D FIIA \\ Department of Economics, Delta State University, Abraka \\ E-mail ionoyere@yahoo.com, Tel: 08038394410
}

\author{
Doi:10.5901/mjss.2014.v5n6p99
}

\begin{abstract}
The practice of microfinance in Nigeria is culturally rooted and dates back to self-Help Groups (SHGs) or Rotating Savings and Credit Association (ROSCAS) types. Microfinance is all about providing financial services to the poor who are traditionally have no access to the conventional financial institutions. A microfinance policy will enhance monetary stability and expand the financial infrastructure of the country to meet the financial requirements of Micro, Small and Medium Enterprises (MSMEs). The major purpose of this policy paper, therefore, is to present a microfinance policy framework for Nigeria that would enhance the provision of diversified microfinance services on a long term sustainable basis for the poor and low income groups. Both theoretical and empirical literature review that Microfinance Banks (MFB) are panacea for unemployment and poverty reduction in developing economies. These problems can be referred to as twin sisters or as Siamese twins (Umo, 2007). The study indentifies the needs for the establishment of Microfinance Banks, microfinance policy and goals, policy strategies, frameworks for the supervision of microfinance banks and the challenges of microfinance Banks (MFBs) in Nigeria. From the findings, the study recommends that the banks should provide diversified, affordable and dependable financial services to the active poor to enable them develop sustainable entrepreneurial activities. The government should as a matter of urgency license, regulate, monitor and evaluate the performance of Microfinance Banks (MFBs) if our objective of sustainable poverty and unemployment reduction is to be achieved now and in the future.
\end{abstract}

Keywords: Microfinance, Microfinance Bank, Unemployment and poverty reduction, Microfinance Policy and Goals.

\section{Introduction}

Robust economic growth and development cannot be achieved without putting in place well focused policies and programmees to reduce unemployment and poverty through empowering the people by increasing their access to factors of production, especially credit facilities. The latent capacity of the poor entrepreneurship would be significantly enhanced through the provision of microfinance services to enable them engage in economic activities and to be more self-reliant, increase employment opportunities, enhance household, individual income, and create wealth. Microfinance is about providing financial services to the poor who are traditionally have no access to the conventional financial institutions. The main feature of microfinance include, the smallness of loans advanced, the absence of asset - based collateral and simplicity of operations. A microfinance policy framework which recognizes the existing informal institutions and brings them within the supervisory purview of the Central Bank of Nigeria (CBN) would not only enhance monetary stability, but also expand the financial infrastructure of the country to meet the financial requirement of the micro, small and Medium Enterprises (MSMEs). Such a policy would harmonise operating standards and provide a strategic platform for the evolution of microfinance institution, promote appropriate regulation, supervision and adoption of best practices. The purpose of this policy paper, therefore, is to present a microfinance policy framework for Nigeria that would enhance the provision of diversified microfinance services on a long term sustainable basis for the poor and low income groups (CBN, 2005).

This policy framework has been prepared in exercise of the powers conferred on the CBN by the provisions of section 28, sub-section (1)(b) of the CBN Act 24 of 1991 (as amended) and in pursuance of the provisions of section 5660 (a) of the Bank and other financial institutions Act (BOFIA) 25 of 1991 (as amended).

\section{Overview of Microfinance Activities in Nigeria}

The practice of microfinance in Nigeria is culturally rooted and dates back several centuries. The traditional microfinance institutions provide access to credit for the rural and urban, low-income earners. They are mainly the informed self-Help 
Groups (SHGs) or Rotating Savings and Credit Associations (ROSCAS) types. The informal financial institutions generally have limited outreach due primarily to paucity of loanable funds. In order to enhance the flow of financial services to Nigeria's rural areas, government has in the part, initiated a series publicly - financed micro/rural credit programmes and policies targeted at the poor. Specifically, some of such programmes include the Rural Banking Programme, Sectoral allocation of credits, concessionary interest rate, the Agricultural Credit Guarantee Scheme (ACGS), the Nigerian Agricultural and Co-operative Bank Limited (NACB), the National Directorate of Employment (NDE), the Nigerian Agricultural Insurance Corporation (NAIC), the Peoples Bank of Nigeria (PBN), the Community Bank (CBs), the Family Economic Advancement Programme (FEAP), the Nigerian Agricultural cooperative and Rural Development Bank Limited (NACRDB) and the National Poverty Eradication Programme (NAPEP) with the mandate of providing financial series to alleviate poverty.

Most of the microfinance services were mainly directed to the agricultural sector and non-farm activities such as trading, tailoring, weaving, bladsmitting, agro-processing and transportation. However, the effects were short-lived, due to the unsustainable nature of the programmes. Be that as it may, the number of non-government organizations (HGOs) involved in microfinance activities have increased significantly in recent times due largely to the inability of the formal financial sector to provide the services needed by the low income groups and the poor, and the declining support from development partners amongst others.

\section{Overview of Unemployment and Poverty Reduction in Nigeria}

Fundamentally, poverty is a negative term denoting absence or lack of material wealth. It is a term usually employed to describe the much more frequent situation of insufficiency either in the possession of wealth or in the flow of income (Seligman and Johnson, 1933). It is a situation in which income is insufficient to meet subsistence needs. Poverty has a lot of detrimental effects hence, it's a very undesirable condition. Poverty creates fear, depression, despondency, revolution, envy, bitterness, self-depreciations of ego, aggraves the rate of desertification and salination poor sanitation (Evbuomwan). Poverty can be reduced by integrating macro-economic policies, sector planning and sound project intervention. All obstructions to the regular flow of income would certainly bring about poverty. At the macro-level, Nigeria is classified as a low income and severally indebted economy, and by implication a poor country (World Bank 1994). This paper has attempted to articulate some contemporary issues in poverty and unemployment with a view to appraising the effectiveness of the policies designed to reduce them in Nigeria.

The Human Development Report (UNDP, 1990), emphasized the importance of studying the multi-dimentional aspects of poverty (nutrition, life expectancy, literacy) rather than simply forecasting upon income levels. Countries with an HDI between 0.5 are considered to have a low level of human development, those between 0.5 and 0.8 medium level and those above 0.8 a high level. The World Development Report (WDR, 1990) considers the mechanisms which governments have at their disposal for overcoming poverty and the measures include those that will increase the income of the poor such, increasing the demand and therefore the price for those factors of production that the poor own (e.g labour), providing social services to the poor (e.g education), transferring physical assets to the poor (e.g land) and transferring current income to the poor (e.g, through cash or food subsidies).

Thus, poverty has both social and economic implications therefore, there is urgent need for the formulation of appropriate policies and programmes so that development will not be impaired.

After three decades of development, both developing countries and major development finance institutions are recognizing that the strategies of economic growth (1960s), income redistribution (1970s) and economic adjustment (1980s) have failed to reduce poverty and unemployment (D'silva and Bysouth, 1992).

Africa in general and Nigeria in particular, there exists high-level of poverty and increasing unemployment rates. Poverty and unemployment are two major development challenges facing Nigeria. High unemployment and poverty rates are pregnant with serious economic, social and political consequences on the economic system.

These two problems have raised a red flag about the quality of development in a stable macroeconomic environment. The problems of poverty and unemployment can be solved vigorously through microfinance policy, regulatory and supervisory framework for the Nigerian economy.

These two problems are not as separate as they appear or mere once conceived by economic analysts. They can be referred to as twin sisters or as Siamese twins (Umo, 2007). Therefore, the policy thrust for dealing with one to a very large extent can be effective in resolving the other. It appears that a consensus is emerging on the idea that the problem of poverty can be solved by vigorously dealing with unemployment through the generation of remunerative and employment opportunities provided by microfinance activities. The idea is based on the linkages between income and poverty (Boateng, 2004). 
Poverty and unemployment is a sourge that has attracted the policy response of the global communities. Fighting the twin sisters problem has therefore become a centered pillar of the economic policy agenda of most governments. The ascendance of Hitler to power in Germany is partly attributed to the extreme inflation and subsequent poverty and unemployment in Germany in the 1920s and 1930s. Unemployment can be defined as a situation where people do not have jobs but are looking for jobs. Poverty has multiple faces such as, unemployment and under employment, the face of a criminal, of a beggar, face of refuges, hunger and malnutrition and the face of exclusion and marginalization. The linkages between unemployment, poverty and output and the implications are the major focus of macroeconomic policies.

\section{Justification for the establishment of Microfinance Banks}

From the examination of the existing microfinance oriented institutions in Nigeria, the following facts have become evident:

1. Weak Institutional capacity. The prolonged sub-optimal performance of many existing community banks in Nigeria, microfinance and development finance Institutions is due to incompetent management, weak internal controls, poor corporate governance and lack of well defined operations and restrictive regulatory/supervisory requirements.

2. The Weak Capital Base of the existing Institutions especially the commercial banks cannot adequately provide a cushion for the risk of lending to micro entrepreneurs without collateral.

3. Economic Empowerment of the poor, employment generation and poverty Reduction. The baseline economic survey of small and medium industries (SMLS) in Nigeria conducted currently employ a little over one million workers. One of the hallmarks of the National Economic Empowerment and Development strategy (NEEDS) is the empowerment of the poor and private sector through the provision of the needed financial services to enable them engage in or expand their present scope of economic activities and generate empowerment. Also, the microfinance policy provide the needed window of opportunities and promote the development of appropriate convenient and easily accessible savings products that would be attractive to all clients and approve the savings level of the economy.

4. The interest of local and International communities in micro financing.

Many international investors have expressed interest in investing in the microfinance sector. Thus, the establishment of a microfinance framework for Nigeria would provide an opportunity for them to finance the economic activities of low income groups and the poor.

5. The microfinance Policy Framework provides an appropriate vehicles that would enhance the utilization of small and medium Enterprises Equity Investment Scheme (SMEEIS) fund.

\section{Microfinance Policy and Goals.}

\subsection{Policy Objectives}

The specific objectives of this microfinance policy are the following:

i. Make financial services accessible to large segment of the potentially productive Nigerian population which otherwise would have little or no access to financial services.

ii. Promote synergy and mainstreaming of the informal sub-sector into the national financial system;

iii. Enhance service delivery by microfinance institutions to micro, small and medium entrepreneurs;

iv. Contribute to rural transformation; and

v. Promote linkage programmers between universal/development banks, specialized institutions and microfinance banks.

\subsection{Policy Targets}

Based on the objectives listed above, the targets of the policy are as follows:

i. To cover the majority of the poor but economically active population by 2020 thereby creating millions of jobs and reducing poverty.

ii. To increase the share of micro credit to the economy from 0.9 percent in 2005 to at least 20 percent in 2020; and share of micro credit as a percentage of GDP from 0.2 percent in 2005 to at least 5percent in 2020. 
iii. To promote the participation of at least two third of the states and local governments in micro credit financing by 2015.

iv. To eliminate gender disparity by improving women's access to financial services by $5 \%$ annual; and

v. To increase the number of linkages among universal banks, development banks, specialized finance institutions and microfinance banks by $10 \%$ annually.

\subsection{Policy Strategies}

A number of strategies have been derived from the objectives and targets as follows:

i. License and regulate the establishment of Microfinance Banks (MFBs)

ii. Promote the establishment of NGO-based microfinance institutions

iii. Promote the participation of Government in the microfinance industry by encouraging States and Local Governments to devote at least one percent of their annual budgets to micro credit initiatives administered through MFBs.

iv. Promote the establishment of institutions that support the development and growth of microfinance service providers and clients;

v. Strengthen the regulatory and supervisory framework for MFBs;

vi. Promote sound microfinance practice by advocating professionalism, transparency and good governance in microfinance institutions;

vii. Mobilized domestic savings and promote the banking culture among low-income groups;

viii. Strengthen the capital base of the existing microfinance institutions;

ix. Broaden the scope of activities of microfinance institutions;

$x$. Strengthen the skills of regulators, operations, and beneficiaries of microfinance initiatives;

xi. Clearly define stakeholders roles in the development of the microfinance sub-sector; and

xii. Collaborate with donors. Coordinate and monitor donor assistance in microfinance in line with the provisions of this policy.

\subsection{The Goals of Microfinance Banks}

The establishment of microfinance banks has become imperative to serve the following purpose:

(i) Provide diversified, affordable and dependable financial services to the active poor, in a timely competitive manner, that would enable them to undertake and develop long-term, sustainable entrepreneurial activities;

(ii) Mobilize savings for intermediation;

(iii) Create employment opportunities and increase the productivity of the active poor in the country, thereby increasing their individual household income and uplifting their standard of living;

(iv) Enhance organized systematic and focused participation on the poor in the socio-economic development and resource allocation process;

(v) Provide veritable avenues for the administration of micro credit programs of government and high net worth individuals on a non-recourse basis. In particular, this policy ensures that state government shall dedicate an amount of not less than $1 \%$ of their annual budget for the on-lending activities of microfinance banks in favour of their residents; and

(vi) Render payment services, such as salaries, gratuities, and pensions for various tiers of government

\section{Ownership of Microfinance Banks}

Microfinance banks can be established by individuals, groups of individuals, community development associates, private corporate entities, or foreign investors. Significant ownership diversification shall be encouraged to enhance good corporate governance of licensed MFBs.

Universal banks that intend to set up any of two categories of MFB as subsidiaries shall be required to deposit the appropriate minimum paid-up capital and meet the prescribed prudential requirements and if, in the view of the regulatory authorities, have also satisfied all the requirements stipulated in the guidelines, shall be licensed.

8.2 No individual, group of individuals, their proxies or corporate entities, and/or their subsidiaries, shall establish more than one MFB under a different or disguised name. 


\section{Frameworks for the Supervision of Microfinance Banks}

\subsection{Licensing and Supervision of Microfinance Banks}

The licensing of microfinance banks shall be the responsibility of the Central Bank of Nigeria. A licensed institution shall be required to add "microfinance bank" after its name. all such names shall be registered with the Corporate Affairs Commission (CAC), in compliance with the Companies and Allied Matters Acts (CAMA) 1990.

\subsection{Establishment of a National Microfinance Consultative Committee}

A National Microfinance Consultative Committee (NMFCC) shall be constituted by the Central Bank of Nigeria (CBN) to provide direction for the implementation and monitoring of this policy. Membership of the Committee shall be determined from time to time by the CBN. The Microfinance Support Unit of the CBN shall serve as the Secretariat to the committee.

\subsection{Credit Reference Bureau}

Due to the peculiar characteristics of microfinance practice, a credit reference bureau, which shall provide information on microfinance clients and aid decision making, is desirable. In this regard, the present Credit Risk Management System in the CBN shall be expanded to serve the needs of the microfinance sector.

\subsection{Deposit Insurance Scheme}

Since MFBs are deposit-taking institutions and in order to reinforce public confidence in them, MFBs shall qualify for the deposit insurance scheme of the Nigeria Deposit Insurance Corporation (NDIC).

\subsection{Management Certification Process}

In order to bridge the technical skills gap, especially among operators of microfinance banks, the policy recognizes the need to set up an appropriate capacity building programme for MFBs. To this end, the CBN shall put in place a microfinance bank management certification process to enhance the acquisition of appropriate microfinance operational skills of the management team of MFBs. A transition period of twenty-four (24) months shall be allowed for the take-off of the programme, with effect from the date of launching the policy.

\subsection{Apex Association of Microfinance Institutions}

The establishment of an apex association of microfinance institutions to promote uniform standards, transparency, good corporate practices and full disclosures in the conduct of MFI businesses shall be encouraged.

\subsection{Establishment of a Microfinance Development Fund}

In order to promote the development of the sub-sector and provide for the wholesale funding requirements of microfinance banks, a Micro Finance Sector Development Fund shall be set up. The Fund shall provide necessary support for the development of the sub-sector in terms of refinancing facility , capacity building, and other promotional activities. The Fund would be sourced from governments and through soft facilities from the international development financing institutions, as well as multilateral and bilateral development institutions.

\subsection{Prudential Requirements}

The CBN recognizes the peculiarities practice and shall accordingly put in place appropriate regulatory and prudential requirements to guide the operations and activities of the microfinance banks.

\subsection{Disclosure of Sources of Funds}

Licensed MFBs shall be required to disclose their sources of funds, in compliance with the Money Laundering Prohibition 


\section{Act 2004}

\section{Corporate Governance of Microfinance Bank}

The board of directors of MFBs shall be primarily responsible for corporate governance in the microfinance banks. To ensure good governance of the banks, the board of directors shall be responsible for the establishing strategies objectives, policies and procedures that would guide and direct the activities of the bank and the means to attain same, as well as the mechanism for monitoring Managements performance. Thus, while management of the day-to-day affairs of the banks shall be the responsibility of the management team, the board of directors shall, however, be responsible for monitoring and overseeing Management's actions. Consequently, the licensed microfinance banks shall be expected to operate under a diversified and professional board of directors.

\section{The Nature of Socio-Economic Dimension of Poverty and Unemployment Rate in Nigeria:}

One major aspect of development is provision of employment opportunities for the citizenry. Unemployment and poverty are persistent and growing problems in Nigeria (Enwioduoki, 2006). This situation was complicated in the part by prolonged period of economic crisis. See table 1 and 2 below:

Table 1: Unemployment Rates in Nigeria by Urban, Rural and National Classification (1976-2010)

\begin{tabular}{|c|c|c|c|}
\hline Year & Urban & Rural & National \\
\hline 1976 & - & - & 4.3 \\
\hline 1980 & - & - & 6.4 \\
\hline 1984 & 7.9 & 4.4 & 6.2 \\
\hline 1985 & 9.8 & 5.2 & 6.1 \\
\hline 1986 & 9.1 & 4.6 & 5.3 \\
\hline 1987 & 9.8 & 6.1 & 7.0 \\
\hline 1988 & 7.8 & 4.8 & 5.3 \\
\hline 1989 & 8.1 & 3.7 & 4.5 \\
\hline 1990 & 5.9 & 3.0 & 3.5 \\
\hline 1991 & 4.9 & 2.7 & 3.1 \\
\hline 1992 & 4.6 & 3.2 & 3.4 \\
\hline 1993 & 3.8 & 2.5 & 2.7 \\
\hline 1994 & 3.2 & 1.7 & 2.0 \\
\hline 1995 & 3.9 & 1.6 & 1.8 \\
\hline 1996 & 6.1 & 2.8 & 3.4 \\
\hline 1997 & 6.0 & 2.6 & 3.2 \\
\hline 1998 & 4.9 & 2.8 & 3.2 \\
\hline 1999 & 5.5 & 2.5 & 3.0 \\
\hline 2000 & 7.2 & 3.7 & 4.7 \\
\hline 2001 & 5.4 & 3.1 & 3.6 \\
\hline 2002 & 5.6 & 3.4 & 3.8 \\
\hline 2003 & 7.7 & 3.5 & 3.9 \\
\hline 2004 & 8.3 & 3.2 & 3.7 \\
\hline 2005 & 8.9 & 3.1 & 3.5 \\
\hline 2006 & 9.2 & 4.5 & 4.1 \\
\hline 2007 & 8.7 & 4.8 & 4.3 \\
\hline 2008 & 8.9 & 4.4 & 5.2 \\
\hline 2009 & 9.2 & 4.7 & 5.4 \\
\hline 2010 & 9.7 & 4.8 & 5.7 \\
\hline
\end{tabular}

Source: Federal Office of Statistics Central Bank of Nigeria 
Table 2 (a): Nigeria Population and Poverty Incidence Trends

\begin{tabular}{|c|c|c|c|}
\hline Year & Estimated Total Population (Million) & Poverty Incidence (Percent) & Population in Poverty (Million) \\
\hline 1980 & 65 & 28.1 & 18.26 \\
\hline 1985 & 75 & 46.1 & 34.73 \\
\hline 1992 & 91.5 & 42.6 & 39.07 \\
\hline 1996 & 102.3 & 65.6 & 67.11 \\
\hline 2004 & 126.3 & 54.4 & 68.70 \\
\hline
\end{tabular}

Source: NLSS (2010)

Table 2 (b): Nigeria Population and Poverty Incidence Trends

\begin{tabular}{|c|c|c|c|}
\hline & Extreme Poor & Moderate Poor & Non-Poor \\
\hline National & 22.04 & 32.38 & 45.58 \\
\hline Urban & 15.64 & 27.54 & 56.81 \\
\hline Rural & 27.08 & 36.19 & 36.73 \\
\hline
\end{tabular}

\section{Source: NLSS (2010)}

Table 2 (c): Poverty Incident by Gender of Household Head

\begin{tabular}{|c|c|c|c|c|}
\hline & \multicolumn{2}{|c|}{ Male Headed } & \multicolumn{2}{c|}{ Female Headed } \\
\hline & Poor & Non-Poor & Poor & Non-Poor \\
\hline All & 56.49 & 43.51 & 36.54 & 63.46 \\
\hline Urban & 44.28 & 55.72 & 34.77 & 65.23 \\
\hline Rural & 65.90 & 34.10 & 38.23 & 561.77 \\
\hline
\end{tabular}

Source: NLSS (2010)

Table 2 (d): Poverty Incident by Different Poverty Lines

\begin{tabular}{|l|c|c|}
\hline \multicolumn{1}{|c|}{ Poverty Line } & Poor & Non-Poor \\
\hline Relative poverty line & 54.41 & 45.59 \\
\hline Absolute poverty line & 54.68 & 45.32 \\
\hline One dollar per day poverty line & 51.55 & 48.45 \\
\hline Self assessment & 50 & 24.50 \\
\hline
\end{tabular}

Source: NLSS (2010)

One of the leading causes of poverty in Nigeria as elsewhere in sub-Sahara Africa, is the shortage of opportunities for gainful employment (Soludo, 2007). The problem of unemployment has posed a great challenge to many countries (both developed and developing). The Nigeria labour market today is characterized by unemployment, low wages and poor working conditions (Chriscose, 1987). Unemployment and poverty have been categorized as two of the staid impediments to social progress. The paper draws heavily from theoretical foundations; examine the nature and magnitude of unemployment in Nigeria as well as the relationship between unemployment and poverty and some critical macroeconomic variables to ascertain the implications of the linkages for the design of credible policy measures to tackle unemployment and poverty in Nigeria. It dwells on the theoretical foundations and conceptual issues.

\section{Challenges Of Microfinance Banks (MFBs) In Nigeria}

Some of the major challenges include poor capitalization and restrictive regulatory and supervisory procedures. The low capital base and the isolated mode of operation have hindered any meaningful contributions to financing activities. A minimum of Paid-up capital of N1.0 billon for a licensed microfinance bank to operate multiple branches within a state can act as serious bottleneck for efficient management of such Banks. Another serious challenges is the restrictive regulatory 
and supervisory guidelines for any NGO-MFI's to convert fully into a microfinance bank. The non review from time to time of the provisions of the policy at the discretion of the regulatory authorities act as serious impediments to effective and efficient performance of Microfinance Banks (MFBs) in Nigeria. Furthermore, there is the problem of an endemic disease (corruption), lack of adequate skilled and skilled professionals in the bank industry. There is also concerted efforts to deliberately not adhering to the microfinance policy, regulatory and supervisory framework for Nigeria by the management of the Banks and the stakeholders.

\section{Conclusion and Recommendations}

\subsection{Conclusion}

This paper has attempted to articulate some contemporary issues in microfinance activities, poverty and unemployment with a view to appraising the effectiveness of Microfinance Banks in reducing poverty and unemployment in Nigeria. The study revealed that microfinance Banks are panacea for poverty and unemployment reduction. The human development report emphasis the importance of studying the multidimensional aspects of poverty (nutrition, life expectancy literacy) and unemployment as fundamental impediments to nations sustainable development. A review of the microfinance policy, regulatory, supervisory framework and strategies for Nigeria are in consonance with what is contained in both the HDR and WDR. A review of microfinance policy, goals, ownership of the banks and framework for the supervision of microfinance banks reports of the various phases revealed that the banks have contributed significantly to improvement in the living standard of the poor and drastic reduction in the rate of unemployment since its inception.

\subsection{Recommendations}

The paper recommends that the banks should provide diversified affordable and dependable financial services to the active poor to enable them to undertake and develop long-time, sustainable entrepreneurial activities. There is the need to create employment opportunities and increase the productivity of the poor in Nigeria thereby increasing their individual household income and therefore uplifting their standard of living. The government should as a matter of urgency license, regulate, monitor and evaluate the performance of Microfinance Banks (MFBs) and also encourage the establishment of NGO-based microfinance institutions to help solve the twin sisters problems of poverty and unemployment. The policy framework should be adequately capitalized, appropriately regulated and supervised to address the need of financing at the micro levels of the economy if our objective of sustainable poverty and unemployment reduction is to be achieved now and in the future.

\section{References}

Boateng, (2004): Youth and ICT Skills in Africa Labour Markets with Particular Reform to Ghana, paper presented at the $3^{\text {rd }}$ Annual Conference of Africa Youths Foundations, 17-19. June Germany.

Chiriscos, T. (1987): Rates of unemployment and crime: An Analysis of Aggregate research Evidence Social Problems.

D'Silva and BySouth. (1992): Poverty Alleviation through Agricultural projects. Economic development Institute of the World Bank. Policy Seminar Report No. 30.

Evbuomwan, G.O (1997): Poverty Alleviation through Agricultural Projects: A review of the concept of the World bank Assisted Agricultural Development Projects in Nigeria, Published in Bulletin July/September, 1997.

Onwioduoki, E.A. (2006): Character of Unemployment in Nigeria and its links with the Macroeconomics in the Nigerian Economy Society. Seligman and Johnson (1933): Encyclopedia of the Sciences the Macmillan Company, U.S.A.

Soludo, C.C. (2007): Macroeconomics, Monetary and financial sector development in Nigeria. CBN website.www.centbanks.org. Central bank of Nigeria, Abuja Dec, 2005.

Umo, Ju. (2007): Economics: An African Perspective Millennium Test Publishers Ltd. 


\section{Appendix I}

Distinguishing Features between a Microfinance Bank and a Universal Bank

\begin{tabular}{|c|c|c|c|c|}
\hline & Criteria & $\begin{array}{c}\text { Microfinance Bank Licensed to } \\
\text { Operate as a unit bank (a.k.a } \\
\text { Community Bank) }\end{array}$ & $\begin{array}{l}\text { Microfinance Bank Licensed to } \\
\text { Operate in a State }\end{array}$ & Universal Bank \\
\hline$A$ & $\begin{array}{l}\text { Minimum paid-up } \\
\text { capital/shareholders' } \\
\text { funds }\end{array}$ & $\begin{array}{l}\text { N20.0 million (increased from N5.0 } \\
\text { million) }\end{array}$ & N1.0 billion & N25.0 billion \\
\hline B & $\begin{array}{l}\text { Scope of activities } \\
\text { covered by License }\end{array}$ & \begin{tabular}{|c|} 
To operate within a Local \\
Government Area. Not to engage in \\
sophisticated banking services, \\
such as forex business.
\end{tabular} & $\begin{array}{c}\text { To operate within a Stat Not to } \\
\text { engage in sophisticated banking } \\
\text { services, such as forex business but } \\
\text { can receive tenured loans and equity } \\
\text { form abroad. }\end{array}$ & $\begin{array}{l}\text { To operate nationally and in } \\
\text { internationally markets. To } \\
\text { operate forex transactions and } \\
\text { domiciliary Accounts for } \\
\text { customers. }\end{array}$ \\
\hline C & $\begin{array}{l}\text { Limitation on credit to an } \\
\text { individual or company }\end{array}$ & $\begin{array}{l}\text { Credit subject to a single obligor } \\
\text { limit of } 1 \% \text { for an } \\
\text { individual/corporate entity and } 5 \% \\
\text { for a group }\end{array}$ & $\begin{array}{l}\text { Credit subject to single obligor limit } \\
\text { of } 1 \% \text { for an individual. Corporate } \\
\text { entity and } 5 \% \text { for a group }\end{array}$ & Single obligor limit applies \\
\hline D & $\begin{array}{l}\text { Limitations on deposits } \\
\text { from an individual or a } \\
\text { company }\end{array}$ & No limit & No limit & No limit \\
\hline$E$ & $\begin{array}{l}\text { Access to public sector } \\
\text { deposits }\end{array}$ & $\begin{array}{l}\text { Permitted for only micro-credit } \\
\text { programmes on a non-recourse } \\
\text { basis and for payment purposes }\end{array}$ & $\begin{array}{l}\text { Permitted for only micro-credit } \\
\text { programmes on a non-recourse } \\
\text { basis and for payment purposes }\end{array}$ & Permitted \\
\hline$F$ & Cheque writing accounts & $\begin{array}{l}\text { Cheque issuing customized o the } \\
\text { correspondent bank }\end{array}$ & $\begin{array}{l}\text { Cheque issuing customized to the } \\
\text { correspondent bank }\end{array}$ & Cheque issuing permitted \\
\hline G & Geographical coverage & In rural and urban areas & $\begin{array}{l}\text { Must operate in both rural and urban } \\
\text { areas prescribed by the CBN }\end{array}$ & $\begin{array}{c}\text { All parts of Nigeria and foreign } \\
\text { branches and subsidiaries }\end{array}$ \\
\hline
\end{tabular}

* The central Bank of Nigeria (CBN) shall define the rural/urban areas for the purpose of this policy 
